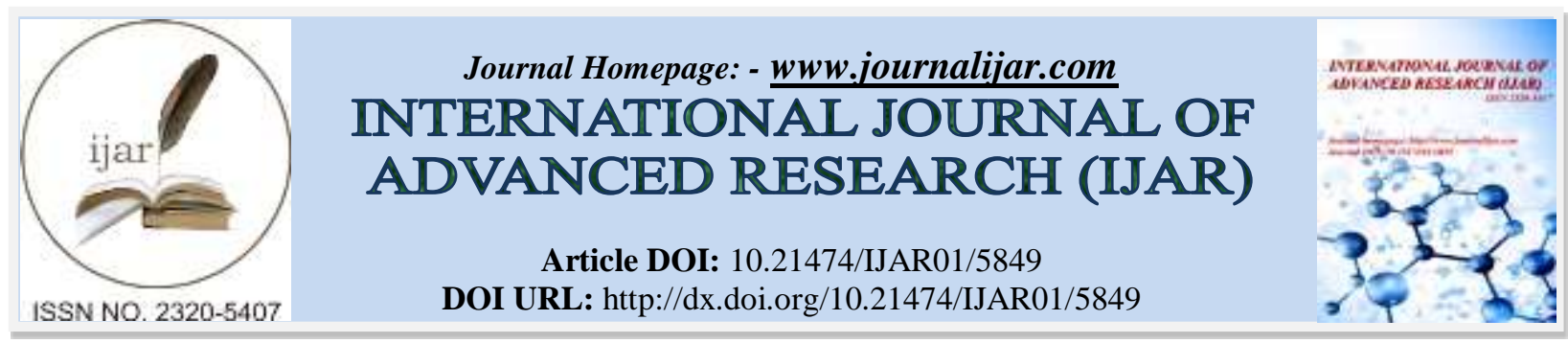

RESEARCH ARTICLE

\title{
COMPARISON OF ESSENTIAL OILS COMPOSITION FROM DIFFERENT ACCESSIONS OF CYMBOPOGON CITRATUS (DC) STAFF.
}

\author{
Archana P J. \\ Post Graduate and Research Department of Botany \& Biotechnology Sree Narayana College, Kollam, Kerala, \\ India. PIN: 691001.
}

\section{Manuscript Info}

Manuscript History

Received: 13 September 2017

Final Accepted: 15 October 2017

Published: November 2017

Key words:-

Accessions, Essential Oil, Gc-Ms Analysis.

\begin{abstract}
The genus Cymbopogon of poaceae family are known to possess essential oil rich in citral content. Comparative study on the essential oil constituents of Cymbopogon is the useful tool in the assessment of diversity. The present investigation different accessions of Cymbopogon citratus were collected from various locations of Kerala assigned with different accession numbers. The essential oil were extracted by Hydro-distillation and subjected to analysis of oil yield and identification of major chemical components.
\end{abstract}

Copy Right, IJAR, 2017,. All rights reserved.

\section{Introduction:-}

The Cymbopogon genus has about 140 species out of which 45 have been reported from India (Jagadish,1975). Cymbopogon which show morphological variation due to hybridization and the selection through human intervention has lead to variations in chemotypic characters across geographical distribution of this species (Kuriakose 1995). This plant is one of the most widely grown essential oil plants in the tropics and subtropics of India, Madagascar, Indonesia and countries in Africa and South America. Cymbopogon species are morphologically indistinguishable (Khanuja et al. 2005; Sangwan et al. 2001). Citral ( neral + geranial) and geranyl acetate are widely used in pharmaceutical and flavouring purpose. Investigations have shown that the herb and oil yield of lemongrass decreased with increase the salinity of irrigation water and the increase of soil fertility had no significant effect on the yield (Prasad et al.2001). During the present study the accessions of C.citratus collected from various ecological regions. They are subjected to the analysis of essential oil to study the variation in the content and composition of the oil for exploring them towards commercial purpose. The essential oil rich in vitamin A and the oil extracted by steam distillation are widely used in aromatherapy. The properties of essential oil include antimicrobial, antifungal, antiseptic, insecticidal, astringent, febrifuge and antidepresent (Grenera 2008). Cymbopogon is contain citral-b and citral-a, while the oil is distilled from leaves and infloresence. Lemongrass is native to India and has been producing essential oil of 1700 tons but current level production has come down to 200 tons. The essential oil of Cymbopogon are comprises of monoterpenes mainly the acyclic monoterpene aldehyde citral, which accounts for 80-90\% of the total monoterpene (Ganjewala and Gupta 2013). The composition and oil content were studied and chemical constituents of the essential oil were also estimated at both vegetative and flowering time. It was observed that the citral content was increased during the flowering season.

Corresponding Author:- Archana P J

Address:- Post Graduate and Research Department of Botany \& Biotechnology, Sree Narayana College, Kollam, Kerala, India. PIN: 691001. 


\section{Materials and Methods:-}

Collection and identification:-

The $C$. citratus collected from different ecological regions of Kerala. There are four accessions are numbered as Cc 1 to Cc 4 (Table 1). The plant samples were collected from Ponmudi hills, Muthanga forest, Vagamon hills and Agasthya Mala .The plant samples are taxonomically identified according to the previous taxonomical clarified records (Sreekumar et al.1990). Morphologically the accessions shows difference in their height on both vegetative and flowering time, number of internodes, number of tiller are recorded during the present study.

\section{Essential oil extraction and analysis:-}

The shade-dried leaves of C.citratus were chopped into small pieces. This leaves materials undergo Hydrodistillation. Collected accessions for various ecological regions gave essential oils with citrus odour. Hydrodistillation of leaf samples $(500 \mathrm{~g})$ from each accessions was done in Clevenger apparatus (Clevenger,1928) for 3 hours .The collected oil dried over anhydrous sodium sulphate $\left(\mathrm{Na}_{2} \mathrm{SO}_{4}\right)$. The The oil undergo refrigeration at $4^{\circ} \mathrm{C}$ prior to analysis. The essential oil composition was determined by GC-MS analysis was carried out with GC-MS 4000.The capillary coloumn was of CP Sil- $8,30 \mathrm{~m} \times 0.25 \mathrm{~mm} \times 0.25 \mu$ thick film. The temperature ranges from $50^{\circ} \mathrm{C}$ to $280^{\circ} \mathrm{C}$ at the rate of $3^{\circ} \mathrm{C} /$ minutes.

\begin{tabular}{|c|c|}
\hline Plant collection locality & Accession representation \\
\hline Ponmudi hills & $\mathrm{Cc} 1$ \\
\hline Muthanga forest & $\mathrm{Cc} 2$ \\
\hline Vagamon hills & $\mathrm{Cc} 3$ \\
\hline Agasthya Mala & $\mathrm{Cc} 4$ \\
\hline
\end{tabular}

Table 1:- Collection of accessions of C.citratus from various ecological regions of Kerala.

\section{Result and Discussion:-}

The essential oils are distilled from plant materials and represent the typical flavour and aroma of Cymbopogon. The oil extracted from this plant material is low and it typically 1 to $3 \%$ of the plant weight. Correct harvesting of this plant is very important for the extraction of essential oil. The essential oil content varies during the growth development of this plant. The chemical constituents of the essential oil were estimated at both vegetative and flowering stage. Finally resulted that the Geraniol, Geraninal, Limonene, Linalool, Citronellal, Neral, Citronellyl acetate, Geranyl acetate and Citral ( Neral + Geranial) were present in the essential oil. The collected accessions C.citratus are taxonomically verified. The taxonomical clarification of the collected accessions are very important. The $\mathrm{Cc} 1, \mathrm{Cc} 2, \mathrm{Cc} 3, \mathrm{Cc} 4$ accessions are collected from different locality of Kerala and identified their morphological characters such as vegetative growth stage height, flowering growth stage height, number of internodes present and number of tillers arised from the C.citratus. Hydro-distillation of leaf samples done for the identification of the percentage of essential oil obtained. GC-MS analysis was done for the proper identification of chemical contents are present in the extracted essential oil by using Hydro-distillation method (Table 2) .

Table 2:- Morphological characters of the four accessions of $C$. citratus and essential oil percentage.

\begin{tabular}{|c|c|c|c|c|c|c|}
\hline Accessions & $\begin{array}{c}\text { Vegetative } \\
\text { Plant height } \\
(\mathbf{c m})\end{array}$ & $\begin{array}{c}\text { Flowering } \\
\text { Plant } \\
\text { height(cm) }\end{array}$ & $\begin{array}{c}\text { No.of } \\
\text { internodes } \\
\text { (cm) }\end{array}$ & $\begin{array}{l}\text { No.of } \\
\text { tillers } \\
(\mathbf{c m})\end{array}$ & $\begin{array}{c}\text { Leaf oil yield } \\
(\boldsymbol{\%})\end{array}$ & $\begin{array}{c}\text { Major compound } \\
(\mathbf{\%})\end{array}$ \\
\hline Cc 1 & 60.75 & 275.62 & 16 & 65.40 & 0.68 & Citral (75-89) \\
\hline Cc 2 & 145.78 & 234.89 & 10 & 56.87 & 0.01 & Citral (64-86) \\
\hline Cc 3 & 101.66 & 186.07 & 14 & 45.68 & 0.13 & Citral (81-92) \\
\hline Cc 4 & 135.11 & 259.68 & 11 & 52.60 & 0.34 & Citral (60-88) \\
\hline
\end{tabular}

The chemical constituents of the essential oil are tabulated and analysed the percentage of the chemical components are present in the isolated essential oil from C.citratus accessions. The major chemical components are identified from this C.citratus accession are Geraniol, Geraninal, Limonene, Linalool, Citronella, Neral, Citronellyl acetate , Geranyl acetate, Citral (Neral+Geraninal). The Cc1 accession have $0.68 \%$ oil yield, Geraniol (5.78\%), Geraninal $(9.36 \%)$, Limonene $(0.1 \%)$, Linalool $(0.21 \%)$, Citronella $(0.62 \%)$, Neral( $4.61 \%)$, Citronellyl acetate $(0.21 \%)$, Geranyl acetate $(8.92 \%)$, Citral (13.92\%). The Cc1 accession comparatively produce high oil yield $(0.68 \%)$ and Geraninal (9.36\%) than other accession. The Cc 2 accessions have $0.01 \%$ oil yield, Geraniol (3.56\%), Geraninal $(8.70 \%)$, Limonene (0\%), Linalool (0.43\%), Citronellal(0\%), Neral (3.62\%), Citronellyl acetate (0.43\%), Geranyl 
acetate (9.21\%), Citral (12.32\%). The Cc 3 accessions have $0.13 \%$ oil yield, Geraniol (4.65 \%), Geraninal (9.10 $\%)$, Limonene (0 \%), Linalool $(0.36 \%)$, Citronellal $(0.50 \%)$, Neral (1.63\%), Citronellyl acetate $(0.53 \%)$, Geranyl acetate $(7.51 \%)$, Citral $(16.61 \%)$. The Cc 3 accession comparatively produce high citral $(16.61 \%)$ than other accession. The Cc 4 accessions have $0.34 \%$ oil yield, Geraniol (3.93 \%), Geraninal (9.21 \%), Limonene (0.1 \%), Linalool (0.11\%), Citronellal(0.50\%), Neral ( $2.50 \%)$, Citronellyl acetate $(0.12 \%)$, Geranyl acetate $(9.77 \%)$, Citral $(11.71 \%)$.

The oil yield and constituents of the essential oil of the C.citratus accessions are presented in Table 3 .

\begin{tabular}{|c|c|c|c|c|c|c|c|c|c|c|}
\hline $\begin{array}{l}\text { Accessio } \\
\text { ns }\end{array}$ & $\begin{array}{c}\text { Oil } \\
\text { yiel } \\
\mathbf{d}\end{array}$ & $\begin{array}{c}\text { Gerani } \\
\text { ol } \\
(\%)\end{array}$ & $\begin{array}{c}\text { Geranin } \\
\text { al } \\
(\%)\end{array}$ & $\begin{array}{c}\text { Limone } \\
\text { ne } \\
(\%)\end{array}$ & $\begin{array}{c}\text { Linalo } \\
\text { ol } \\
(\%)\end{array}$ & $\begin{array}{c}\text { Citronell } \\
\text { al } \\
(\%)\end{array}$ & $\begin{array}{l}\text { Ner } \\
\text { al } \\
(\%)\end{array}$ & $\begin{array}{l}\text { Citronell } \\
\text { yl } \\
\text { acetate } \\
\quad(\%)\end{array}$ & $\begin{array}{l}\text { Geran } \\
\text { yl } \\
\text { acetate } \\
\quad(\%)\end{array}$ & $\begin{array}{l}\text { Citral } \\
(\text { Neral } \\
+ \\
\text { Gerani } \\
\text { al ) }(\%)\end{array}$ \\
\hline Cc 1 & 0.68 & 5.78 & 9.36 & 0.1 & 0.21 & 0.62 & 4.61 & 0.21 & 8.92 & 13.97 \\
\hline Cc 2 & 0.01 & 3.56 & 8.70 & 0 & 0.43 & 0 & 3.62 & 0.43 & 9.21 & 12.32 \\
\hline Cc 3 & 0.13 & 4.65 & 9.10 & 0 & 0.36 & 0.50 & 1.63 & 0.53 & 7.51 & 16.61 \\
\hline Cc 4 & 0.34 & 3.93 & 9.21 & 0.1 & 0.11 & 0.50 & 2.50 & 0.12 & 9.77 & 11.71 \\
\hline
\end{tabular}

Table 3:- Oil yield and chemical constituents of $C$.citratus accessions are expressed in percentage (\%).

\section{Conclusion:-}

The four accessions of C.citratus shows minute morphological variations. Extraction of the essential oil from the leaf sample of the morphologically examined accessions by using Hydro-distillation method . The chemical constituents of the essential oil are identified using GC-MS analysis. The comparative study of morphology and chemical content of the essential oil resulted that the identification of economically important chemical compounds from collected accessions from different locality.

\section{References:-}

1. Clevenger JF (1928) Apparatus for determination of volatile oil, J.Am Pharm Assn 17:346.

2. Ganjewala D Gupta AK (2013) Leamongrass (Cymbopogon flexuosus Steud. ) Wats Essential Oils. Recent Progress in Medicinal and Aromatic Plants, Studium Press LLC,USA. 35:233-274.

3. Grenera (2008) Nutrients : Lemon Grass Oil. Retrieved from Essential oil. in.

4. Jagadish CKS (1975) Recent studies on Cymbopogon Spreng to Indian Taxas Journal of Plant Crops 3:1-5.

5. Khanuja SPS, Shasany AK Pawar A Lal RK Darokar MP Naqvi AA Rajikumar S Sundaresan V Lal N and Kumar S (2005) Essential oil constituents and RAPD markers to establish species relationship in Cymbopogon Spreng.(Poaceae). Biochem System Ecology. 33:171-186.

6. Kuriakose KP (1995) Genetic variability in East Indian lemon grass (Cymbopogon flexuosus Staf).Indian Perfumer 39:76-83.

7. Prasad A Anwar M Patra DD and Singh DV (2001) Interactive effects of irrigation water salinity and soil fertility on soil salinity and sodicity buildup in soils and yield and cation composition of palmarosa (Cymbopogon martini) and lemongrass (Cymbopogon flexuosus). Journal of the Indian Society of Soil science 49:178-187.

8. Sangwan NS Yadav U and Sangwan RS (2001) Molecular analysis of genetic diversity in elite Indian cultivars of essential oil trade types of aromatic grasses (Cymbopogon species).Plant Cell Report, 20:437-444.

9. Sreekumar PV Nair VJ (1991) Flora of Kerala-Grasses, Botanical Survey Of India 2:68-75. 